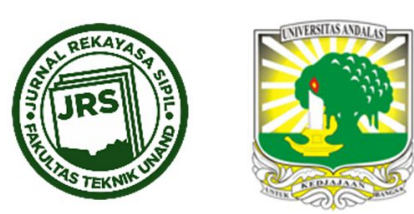

\title{
KARAKTERISTIK BETON MENGGUNAKAN PORTLAND COMPOSITE CEMENT (PCC) DAN SILICA FUME UNTUK APLIKASI STRUKTUR DI DAERAH LAUT
}

\author{
DWI SUSANTO ${ }^{1}$, ZULFIKAR DJAUHARI $^{2}$, MONITA OLIVIA $^{3}$ \\ ${ }^{1}$ Magister Teknik Sipil Jurusan Teknik Sipil Fakultas Teknik Universitas Riau (dwi.susanto7404@grad.unri.ac.id) \\ ²Jurusan Teknik Sipil Fakultas Teknik Universitas Riau (zulfikar.djauhari@lecturer.unriac.id) \\ ${ }^{3}$ Jurusan Teknik Sipil Fakultas Teknik Universitas Riau (corresponding author $₫$ monita.olivia@lecturer.unri.ac.id)
}

Naskah diterima : 17 Maret 2019. Disetujui: 24 April 2019. Diterbitkan : 24 Mei 2019

\begin{abstract}
ABSTRAK
Trend penggunaan semen untuk konstruksi dalam beberapa tahun belakangan ini telah beralih dari tipe Ordinary Portland Cement (OPC) menjadi Portland Composite Cement (PCC). Hal ini berdasarkan kebijakan industri semen untuk mengkonversi sebagian kandungan semen OPC menggunakan material pozzolanik. Oleh karena itu semen tipe PCC lebih mudah diperoleh di pasaran dan telah banyak digunakan sektor konstruksi dalam aplikasi di berbagai lingkungan meski belum banyak diteliti keunggulannya. Pada penelitian ini dikaji karakteristik beton semen PCC untuk aplikasi dermaga di daerah pasang-surut lingkungan air laut. Parameter penelitian adalah penambahan aditif silika dan umur beton yang direndam di air laut. Beton PCC dengan mutu beton $\mathrm{fc}^{\prime}=30 \mathrm{MPa}$ digunakan sebagai campuran kontrol, sedangkan beton PCC dengan tambahan silica fume ( $\mathrm{PCC}+\mathrm{SF})$ sebesar Setelah benda uji dicetak, kemudian benda uji direndam di bak perendaman selama 3 hari dan diletakkan di daerah pasang-surut pelabuhan Belawan, Medan, Sumatera Utara hingga waktu pengujian. Pengujian yang dilakukan adalah kuat tekan, kuat tarik dan porositas setelah benda uji direndam dalam air laut pada umur 28, 91 dan 180 hari. Hasil pengujian menunjukkan bahwa umumnya kuat tekan dan kuat tarik meningkat serta porositas menurun untuk beton PCC dan $\mathrm{PCC}+\mathrm{SF}$ meski direndam di daerah pasang-surut hingga umur 180 hari. Akan tetapi beton $\mathrm{PCC}+\mathrm{SF}$ memiliki karakteristik lebih baik dibandingkan beton PCC dan direkomendasikan untuk beton terpapar air laut di daerah pasang-surut.
\end{abstract}

Kata kunci : air laut, Portland Composite Cement, Silica Fume, Kuat Tekan, Porositas

\section{PENDAhULUAN}

Indonesia merupakan negara kepulauan dan mayoritas kota-kota besar terletak di pesisir laut. Berbagai bangunan dan infrastruktur seperti dermaga, jembatan, dinding penahan tanah dibangun di lingkungan air laut, baik di zona pasang-surut maupun terendam di dalam laut. Untuk keperluan pembangunan tersebut, struktur beton masih merupakan 
pilihan utama karena beton masih relatif murah, mudah diperoleh, mudah dikerjakan, kuat dan mudah dibentuk dalam pelaksanaan pekerjaan di lapangan.

Trend penggunaan semen di Indonesia telah beralih dari jenis Ordinary Portland Cement (OPC) menjadi Portland Composite Cement (PCC) pada dekade ini. Perbandingan penggunaan semen PCC dibanding semen OPC adalah sekitar 80:20. Penggunaan semen PCC yang terus meningkat dalam proyek-proyek besar seperti proyek di lingkungan air laut, menjadikan semen PCC mudah diperoleh di pasaran. Harga semen tipe PCC lebih murah dibandingkan dengan tipe OPC, sehingga kecenderungan pemakaian semen tipe PCC semakin meningkat.

Semen PCC merupakan bahan pengikat hidrolisis hasil penggilingan bersama-sama terak semen Portland dan gypsum dengan satu atau lebih bahan anorganik, atau hasil pencampuran antara bubuk semen Portland dengan bubuk bahan anorganik lain seperti terak tanur tinggi (slag), pozzolan, senyawa silikat, batu kapur dengan kadar total bahan anorganik 6-35\% dari massa semen Portland komposit (SNI, 2004). Menurut Supartono (2001) bahan-bahan anorganik tersebut merupakan bahan-bahan mineral bersifat pozzolanik. Bahan pozzolanik adalah bahan mineral yang unsur-unsurnya tidak memiliki sifat semen secara mandiri, namun bila bereaksi dengan kalsium-oksida dan air pada suhu biasa dapat membentuk senyawa seperti semen (cementitious). Pada umumnya semen PCC memiliki panas hindrasi rendah sampai sedang, tahan terhadap serangan sulfat, kekuatan tekan awal kurang, namun kekuatan akhir lebih tinggi.

Pada bangunan di lingkungan air laut, semen yang direkomendasikan adalah semen tipe $\mathrm{V}$ atau semen tahan sulfat (Mulyono, 2004). Akan tetapi karena semen tipe V tidak dapat diperoleh dengan mudah dari industri semen serta memerlukan biaya tambahan, maka untuk memudahkan pembangunan perlu dikaji penggunaan semen PCC untuk aplikasi di lingkungan air laut. Pada penelitian ini akan diteliti kuat tekan, kuat tarik, dan porositas beton menggunakan semen PCC dan PCC ditambah silica fume setelah direndam pada umur 28, 91, dan 180 hari secara langsung di air laut.

\section{BETON PADA LINGKUNGAN LAUT}

Lingkungan laut memiliki zona pasang surut. Saat pasang terjadi, struktur akan terendam dalam air dan saat surut garam dari air laut akan tertinggal di struktur. Beton rentan terhadap keretakan yang disebabkan oleh abrasi, erosi, benturan serta reaksi kimia antara ion-ion agresif dalam air laut pada zona ini. Air laut mengandung 3,5\% larutan garam yang terdiri dari $78 \%$ sodium klorida $(\mathrm{NaCl})$ dan $15 \%$ magnesium sulfat $\left(\mathrm{MgSO}_{4}\right)$ (Labib, Setyawan, \& Sumarsono, 2016). Air laut memberikan dampak negatif terhadap ketahanan beton karena mengandung garam-garaman yang dapat merusak keawetan dan besi bertulang dalam beton. Hal ini disebabkan ion klorida $(\mathrm{Cl})$ pada air laut merupakan garam agresif terhadap bahan lain, termasuk beton. Kerusakan dapat terjadi pada beton akibat reaksi antara ion klorida yang masuk ke dalam beton dan bereaksi dengan senyawa-senyawa lain sehingga beton kehilangan sebagian massa, kehilangan kekuatan dan kekakuannya serta mengalami proses pelapukan (Mehta, 1991). Pelapukan pada selimut beton mengakibatkan timbul retak-retak pada permukaan beton, lalu beton mulai pecah, lalu tulangan yang terpapar udara dan air akan berkarat sehingga masa layan beton akan berkurang (Sudjono, 2005). Disamping itu permeabilitas beton di lingkungan air laut merupakan salah satu faktor penting untuk ketahanan beton di lingkungan laut. Beton yang memiliki permeabilitas tinggi akan memudahkan air laut masuk ke bagian dalam beton sehingga mikrostruktur dan $\mathrm{pH}$ beton akan terganggu (Ping, et al. 1999). 
Pozzolan juga dapat dipakai sebagai bahan tambah atau pengganti sebagian semen Portland. Bila pozzolan dipakai sebagai bahan tambah akan menjadikan beton menjadi lebih mudah diaduk, lebih rapat air dan lebih tahan terhadap serangan kimia. Beberapa pozzolan dapat mengurangi pemuaian akibat proses alkali-agregat (reaksi alkali dalam semen dengan silika dalam agregat), dengan demikian mengurangi retak-retak beton akibat reaksi tersebut. Pada pembuatan beton massa pemakaian pozzolan sangat menguntungkan karena menghemat semen dan mengurangi panas hidrasi (Tjokrodimuljo,1996).

Untuk mendapatkan beton yang tahan terhadap lingkungan agresif seperti air laut adalah dengan menggunakan bahan tambah mineral dan kimia. Jenis bahan tambah mineral seperti abu terbang, slag, dan silicafume juga banyak dicampurkan ke dalam beton (Supartono, 2001) dalam (Olivia \& Indrawan, 2013). Hal ini bertujuan untuk meningkatkan kekedapan beton, menurunkan permeabilitas, mengurangi akses zat cair sehingga air dan ion-ion agresif seperti klorida tidak dapat masuk ke dalam beton dengan mudah. Keandalan beton terhadap lingkungan yang kedap air ditentukan oleh tingkat penyerapan air pada permukaan beton yang disebut absorpsi. Nilai absorpsi yang besar pada beton merupakan indikasi beton tersebut kurang awet atau memiliki durabilitas yang rendah karena beton dengan mudah menyerap air dan hal ini meyebabkan degradasi kekuatan beton.

Silica fume merupakan salah satu bahan tambah mineral yang dapat meningkatkan kekedapan beton, menurunkan permeabilitas, mengurangi akses zat cair sehingga air dan ion-ion agresif seperti klorida tidak dapat masuk ke dalam beton dengan mudah melalui reaksi pozzolanik (King, 2012). Pemakaian silica fume pada beton menyebabkan nilai kuat tekan beton yang dihasilkan lebih tinggi, karena unsur $\mathrm{SiO}_{2}$ pada silica fume bereaksi dengan kapur mati $\mathrm{Ca}(\mathrm{OH})_{2}$ hasil hidrasi antara semen dan air. Kapur hidrolisis sebagai perekat yang menambah kekuatan dari kepadatan beton akan terbentuk meskipun reaksi ini cenderung berlangsung lambat. Penambahan silica fume pada campuran beton akan meningkatkan kadar $\mathrm{SiO}_{2}$ untuk membentuk senyawa Calcium Silicate Hydrate (CSH) setelah bereaksi dengan kapur bebas $\mathrm{CaO}$ dan kapur mati $\mathrm{Ca}(\mathrm{OH})_{2}$, sehingga daya lekat antara pasta semen dengan agregat semakin kuat. Daya lekat antara pasta semen dengan agregat semakin kuat karena silica fume memiliki sifat pozzolan yang akan bereaksi dengan $\mathrm{Ca}(\mathrm{OH})_{2}$ yang merupakan produk sampingan hidrasi semen yang terkumpul di daerah Interfacial Transition Zone (ITZ) lalu membentuk senyawa CSH.

Pemakaian silica fume pada beton menyebabkan nilai rembesan beton yang dihasilkan lebih kecil, karena silica fume dapat berfungsi sebagai filler. Silica fume mudah menyebar di sekeliling butiran semen pada waktu campuran beton baru dibuat, untuk menggantikan air yang terdapat pada ruang-ruang kosong tersebut terisi air yang terjebak oleh partikelpartikel semen dan akhirnya menguap membentuk rongga-rongga yang berakibat pada meningkatnya nilai permeabilitas beton (Sudarmoko, 1990).

\section{METODOLOGI PENELITIAN}

Bahan penyusun beton meliputi agregat kasar, agregat halus, semen PCC, silica fume, dan air. Agregat kasar berasal dari Binjai, Sumatera Utara, memiliki berat jenis SSD $=2,68$, absorpsi 1, 21\%, dan kadar air 0,1\%. Agregat halus memiliki berat jenis 2,59 dengan modulus kehalusan 2,57, absorpsi 2,56\%, dan kadar air 2,25\%. Agregat kasar dan halus memenuhi spesifikasi dan cocok digunakan sebagai bahan penyusun beton dalam penelitian ini. Semen PCC berasal dari PT. Semen Padang dengan komposisi kimia dan fisika dapat dilihat pada Tabel 1. Air yang digunakan adalah air tawar berasal dari tanah. 
Tabel 1. Karakteristik Portland Cement Composite (PCC) dari PT. Semen Padang

\begin{tabular}{|c|c|c|c|c|c|}
\hline No. & Pengujian & Satuan & $\begin{array}{l}\text { Metode Uji } \\
\text { SNI 15-2049- } \\
2004\end{array}$ & $\begin{array}{l}\text { Hasil } \\
\text { Uji }\end{array}$ & $\begin{array}{l}\text { Persyaratan } \\
\text { Standar SNI } \\
15-2049-2004\end{array}$ \\
\hline \multicolumn{6}{|c|}{ KOMPOSISI KIMIA } \\
\hline 1 & Bagian tak larut & $\%$ & Point.7.1.3.1 & 8,12 & \\
\hline 2 & $\begin{array}{l}\text { Magnesium oksida } \\
(\mathrm{MgO})\end{array}$ & $\%$ & Point.7.1.3.10 & 0,63 & 4,00 maks \\
\hline 3 & $\begin{array}{l}\text { Sulfur trioksida } \\
\left(\mathrm{SO}_{3}\right)\end{array}$ & $\%$ & Point.7.1.3.11 & 1,78 & \\
\hline 4 & Hilang pijar & $\%$ & Point.7.1.3.12 & 4,60 & \\
\hline 5 & $\begin{array}{l}\text { Total Alkali } \\
\left(\mathrm{Na}_{2} \mathrm{O}+0,658 \mathrm{~K}_{2} \mathrm{O}\right)\end{array}$ & $\%$ & Point.7.1.3.13 & 0,52 & \\
\hline \multicolumn{6}{|c|}{ KOMPOSISI FISIKA } \\
\hline 6 & $\begin{array}{l}\text { Kehalusan dengan } \\
\text { alat Blaine }\end{array}$ & $\mathrm{m}^{2} / \mathrm{kg}$ & Point.7.2.2.1 & 361 & $280 \mathrm{~min}$ \\
\hline 7 & $\begin{array}{l}\text { Kekekalan } \\
\text { pemuaian dengan } \\
\text { autoclave }\end{array}$ & $\%$ & Point.7.2.5 & 0,08 & 0,20 maks \\
\hline \multirow[t]{3}{*}{8} & $\begin{array}{l}\text { Waktu Pengikatan } \\
\text { dengan alat Vicat }\end{array}$ & & & & \\
\hline & Ikat awal & menit & Point.7.2.4,5 & 145 & $45 \mathrm{~min}$ \\
\hline & Ikat akhir & menit & Point.7.2.4.5 & 228 & 375 maks \\
\hline \multirow[t]{4}{*}{9} & $\begin{array}{l}\text { Kekuatan tekan } \\
\text { (mortar) }\end{array}$ & & & & \\
\hline & 3 hari & $\mathrm{kg} / \mathrm{cm}^{2}$ & Point.7.2.6 & 182 & $125 \mathrm{~min}$ \\
\hline & 7 hari & $\mathrm{kg} / \mathrm{cm}^{2}$ & Point.7.2.6 & 246 & $200 \min$ \\
\hline & 28 hari & $\mathrm{kg} / \mathrm{cm}^{2}$ & Point.7.2.6 & 335 & $250 \mathrm{~min}$ \\
\hline 10 & Pengikatan semu & $\%$ & & 71,08 & $50 \mathrm{~min}$ \\
\hline
\end{tabular}

Karakteristik silica fume sebagai bahan tambah dapat dilihat pada Tabel 2. Kadar kandungan senyawa silika-dioksida $\left(\mathrm{SiO}_{2}\right)$ pada silica fume produksi Master Life BASF adalah $95,84 \%$. Nilai ini termasuk sangat tinggi (> 90\%). Ukuran butiran partikelnya yang sangat halus, yaitu sekitar 1/100 ukuran rata-rata partikel semen sehingga dapat meningkatkan kinerja beton. Pada penelitian ini silica fume sebesar $7 \%$ digunakan sebagai bahan tambah pada beton PCC-silica fume ( $\mathrm{PCC}+\mathrm{SF})$. Dosis silica fume yang direkomendasikan oleh BASF (supplier) berkisar antara 5-15\% dari berat semen.

Tabel 2. Karakteristik silica fume

\begin{tabular}{llll}
\hline No. & Komponen & Satuan & Hasil \\
\hline 1 & Silicone dioxide $\left(\mathrm{SiO}_{2}\right)$ & $\%$ & 95,84 \\
\hline 2 & Moisture & $\%$ & 0,11 \\
\hline 3 & Loss of Ignition $(\mathrm{LOI})$ & $\%$ & 1,00 \\
\hline 4 & Bulk density & $\mathrm{kg} / \mathrm{m}^{3}$ & 540 \\
\hline
\end{tabular}

Komposisi beton yang digunakan dalam penelitian ini dapat dilihat pada Tabel 3 .

Tabel 3. Komposisi Beton PCC dan PCC-silica fume $(\mathrm{PCC}+\mathrm{SF})$ dengan $\mathrm{fc}=30 \mathrm{MPa}$ per $\mathrm{m}^{3}$

\begin{tabular}{llllllll}
\hline & & \multicolumn{5}{c}{ Komposisi beton } \\
\cline { 2 - 7 } No. $\begin{array}{l}\text { Jenis } \\
\text { Beton }\end{array}$ & $\begin{array}{l}\text { Semen } \\
(\mathrm{kg})\end{array}$ & $\begin{array}{l}\text { Agregat } \\
\text { Kasar }(\mathrm{kg})\end{array}$ & $\begin{array}{l}\text { Agregat } \\
\text { Halus } \\
(\mathrm{kg})\end{array}$ & $\begin{array}{l}\text { Air } \\
(\mathrm{L})\end{array}$ & $\begin{array}{l}\text { Silica } \\
\text { Fume } \\
(\mathrm{kg})\end{array}$ & $\begin{array}{l}\text { SP* } \\
(\mathrm{L})\end{array}$ \\
\hline 1 & PCC & 440 & 1123 & 659 & 184,80 & - & - \\
\hline 2 & PCC+SF & 420 & 1142 & 700 & 168 & 29,40 & 3,78 \\
\hline
\end{tabular}

4 | JURNAL REKAYASA SIPIL 
*SP $=$ Superlasticizer

Bahan penyusun beton dapat dilihat pada Gambar 1. Pada penelitian ini superplasticizer atau high range water reducer diperlukan untuk mengontrol dan menghasilkan nilai slump optimal pada beton segar (workable) sehingga kinerja pengecoran beton lebih baik. Penggunaan superplasticizer sebesar 0,9\% dari berat semen telah sesuai dengan standard ASTM-C 494-81 tipe F.

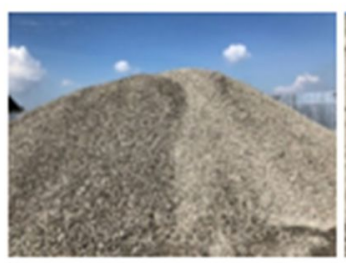

(a)

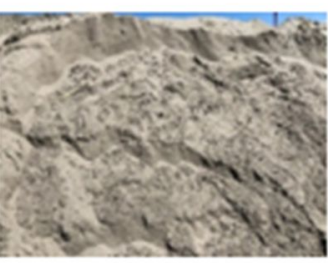

(b)

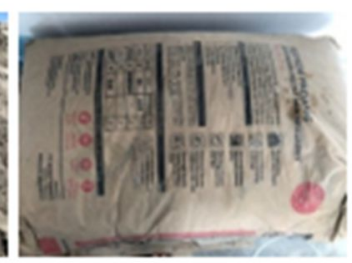

(c)

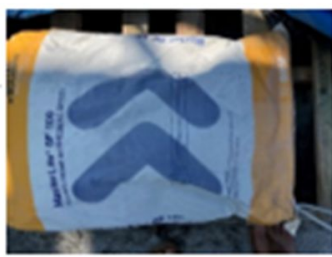

(d)

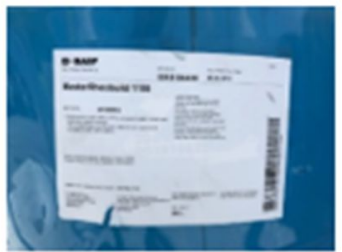

(e)

Gambar 1. Bahan Penyusun Benda Uji (a) Agregat Kasar, (b) Agregat Halus, (c) Semen PCC, (d) Silica Fume, (d) Superplasticizer, (e) Superplasticizer.

Komposisi kimia air laut Belawan, Sumatera Utara, berdasarkan hasil uji dari Balai Riset dan Standarisasi Industri Medan dapat dilihat pada Tabel 4. Air laut dari Belawan mengandung ion klorida $(\mathrm{Cl})$ sebesar 3,0687\% atau 30,687 gram per $1000 \mathrm{~mL}$.

Tabel 4. Komposisi Kimia Air Laut Belawan

\begin{tabular}{llll}
\hline & Komponen & Satuan & Hasil \\
No. & & & \\
\hline 1 & pH & $\mathrm{mg} / \mathrm{l}$ & 8,76 \\
\hline 2 & Posfat $\left(\mathrm{PO}_{4}\right)$ & $\mathrm{mg} / \mathrm{l}$ & 0,06 \\
\hline 3 & Klorida $(\mathrm{Cl})$ & $\mathrm{mg} / \mathrm{l}$ & 30687 \\
\hline 4 & Magnesium $(\mathrm{Mg})$ & $\mathrm{mg} / \mathrm{l}$ & 1516 \\
\hline 5 & Kalsium $(\mathrm{Ca})$ & $\mathrm{mg} / \mathrm{l}$ & 990 \\
\hline 6 & Kalium $(\mathrm{K})$ & $\mathrm{mg} / \mathrm{l}$ & $<0,005$ \\
\hline 7 & Natrium $(\mathrm{Na})$ & 78,1 \\
\hline
\end{tabular}

Pelaksanaan penelitian dimulai dari pemeriksaan bahan penyusun beton yaitu agregat kasar dan agregat halus (gradasi, berat satuan, berat jenis, absorpsi, kadar air), perancangan bahan susun beton/mix design berupa air, semen, agregat kasar, agregat halus, silica fume, superplasticizer. Beton dicampur, diuji slump, dicetak, dan dilakukan pengujian kuat tekan, kuat tarik dan porositas. Pada proses perawatan, benda uji direndam selama 3 hari dalam bak perendaman menggunakan air tawar lalu diletakkan pada area pasang surut di pantai Belawan. Lokasi pengujian dilaksanakan di pelabuhan Belawan, Medan, Sumatera Utara. Koordinat geografis pelabuhan adalah $03^{\circ} 47^{\prime}$ N 98 $42^{\prime}$ E (03⒋ $47^{\prime} 00^{\prime \prime} \mathrm{LU}$ dan $98^{\prime \prime} 42^{\prime \prime} \mathrm{BT}$ ). Pelabuhan ini berjarak sekitar $24 \mathrm{~km}$ dari pusat kota Medan (Gambar 2). 
Benda uji yang digunakan berupa silinder dengan ukuran 150x300 mm untuk kuat tekan dan kuat tarik belah (Gambar 3(a)). Sedangkan uji porositas menggunakan kubus 100x100x100 mm (Gambar 3(b)). Setiap pengujian menggunakan tiga sampel. Pengujian yang dilakukan meliputi kuat tekan, kuat tarik belah, dan porositas. Umur pengujian sampel adalah 7, 28, 91, 180 hari. Uji kuat tekan beton menggunakan peralatan Universal Testing Machine (UTM) dengan standar pengujian mengacu pada SNI 1974:2011. Uji tarik belah beton mengacu pada SNI 240:2014. Uji porositas mengacu pada ASTM C642 atau SNI 036433-2000 dengan menggunakan benda uji beton kubus. Jenis, ukuran, umur pengujian dan jumlah benda uji dapat dilihat pada Tabel 5.

Tabel 5. Jenis, Ukuran, Umur Pengujian dan Jumlah Benda Uji beton PCC dan PCC-SF

\begin{tabular}{llllll}
\hline No. & Pengujian & $\begin{array}{l}\text { Jenis Benda } \\
\text { Uji }\end{array}$ & Ukuran Benda Uji & Umur Pengujian & Jumlah \\
\hline 1 & Kuat tekan & Silinder & $150 \times 300 \mathrm{~mm}$ & $7,28,91,180$ & 24 \\
\hline 2 & $\begin{array}{l}\text { Kuat tarik } \\
\text { belah }\end{array}$ & Silinder & $150 \times 300 \mathrm{~mm}$ & $28,91,180$ & 18 \\
\hline 3 & Porositas & Kubus & $100 \times 100 \times 100 \mathrm{~mm}$ & $28,91,180$ & 18 \\
\hline & & & Total & 60 \\
\hline
\end{tabular}

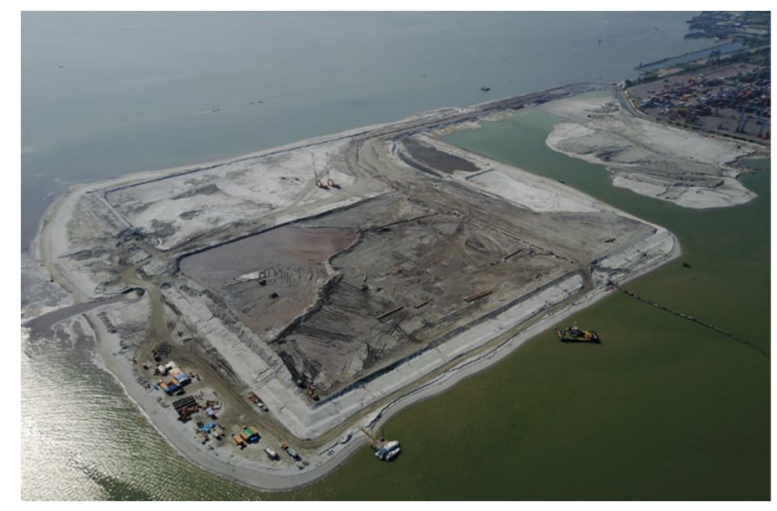

Gambar 2. Lokasi Perendaman Benda Uji di Pelabuhan Belawan, Medan.

Benda uji yang dimasukkan ke daerah pasang surut diletakkan dalam kotak dan dibiarkan terpapar air laut saat pasang-surut hingga saat pengujian dilakukan (Gambar 3(c) dan 3(d)). Pengujian di lapangan atau kondisi sebenarnya memerlukan durasi waktu panjang karena kerusakan oleh air laut diprediksi berlangsung cukup lama.

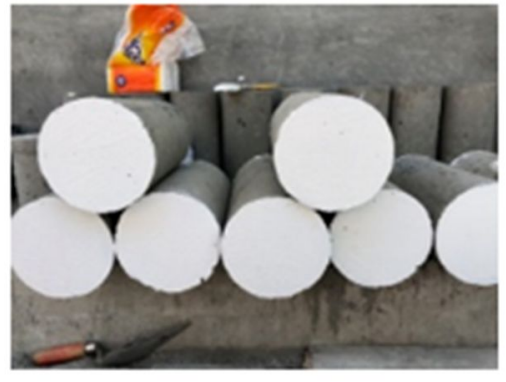

(a)

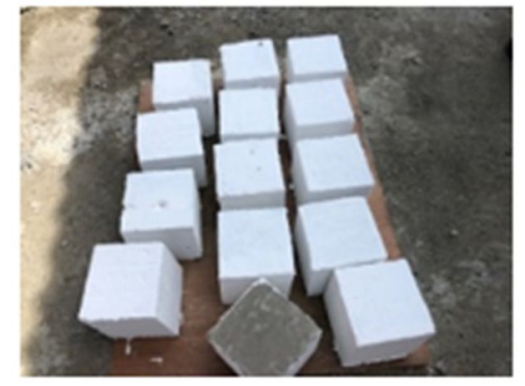

(b) 


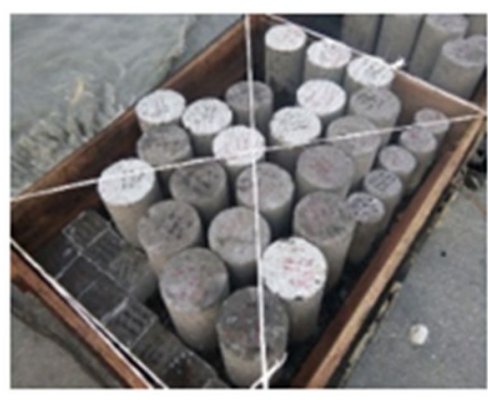

(c)

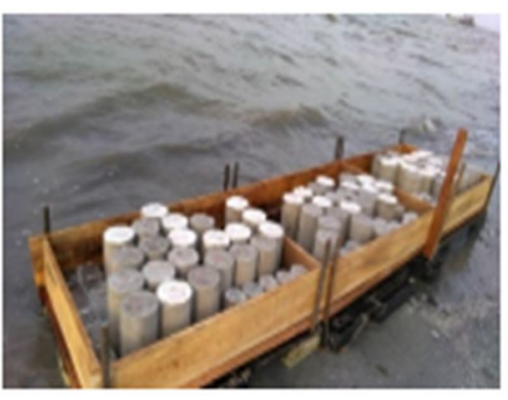

(d)

Gambar 3. Benda Uji (a) Silinder, (b) Kubus, (c) dan (d) Benda Uji di Area Pasang-Surut.

\section{HASIL DAN PEMBAHASAN}

\subsection{Kuat Tekan}

Hasil pengujian kuat tekan beton PCC dan PCC-silica fume (PCC+SF) pada umur 7, 28, 91, dan 180 hari dapat dilihat pada Gambar 4. Secara umum kuat tekan beton meningkat dengan bertambahnya umur beton PCC dan PCC+SF setelah direndam di air laut. Peningkatan kekuatan paling besar terjadi setelah umur 7 hari, yakni sebesar $41,02 \%$ dan $51,87 \%$ untuk beton PCC dan PCC+SF. Setelah 28 hari peningkatan kekuatan beton yang terjadi semakin kecil pada umur 91 hingga umur 180 hari, yaitu sebesar 17,05\% dan 16,53\% untuk beton PCC. Hal yang sama juga dapat dilihat pada beton PCC+SF karena kekuatan hanya bertambah sebesar 21,82\% dan 16,11\% pada umur 91 dan 180 hari. Meski benda uji dirawat pada kondisi pasang-surut di air laut hingga 180 hari, tetapi beton PCC dan PCC+SF masih terus menunjukkan peningkatan kekuatan dalam zona tersebut.

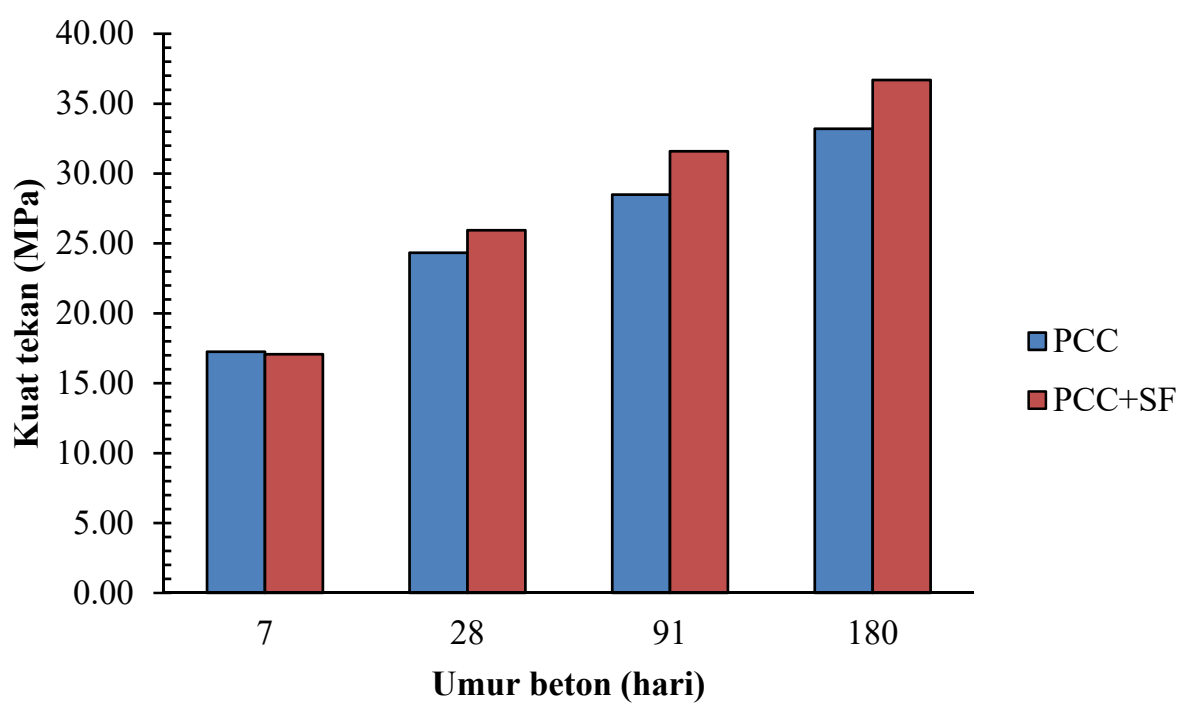

Gambar 4. Kuat tekan beton PCC dan PCC-silica fume di air laut pada umur 7-180 hari.

Berdasarkan hasil pengujian, beton PCC belum mencapai kriteria rencana mutu yang direncanakan sebesar $30 \mathrm{MPa}$ pada umur 28 dan 91 hari, sedangkan beton $\mathrm{PCC}+\mathrm{SF}$ telah mencapai kriteria tersebut pada umur 91 hari. Semen PCC memiliki kandungan pozzolanik 
cukup tinggi, tetapi tidak cukup untuk mencapai kuat tekan rencana pada umur 28 hari setelah direndam di air laut. Penambahan silica fume pada beton $\mathrm{PCC}+\mathrm{SF}$ dapat meningkatkan kekuatan tekan beton secara signifikan sebesar $10 \%$ sehingga mutu yang diinginkan dapat tercapai pada umur 91 hari. Untuk aplikasi lapangan, beton PCC+SF lebih sesuai dibandingkan beton PCC tanpa bahan tambah.

Peningkatan kuat tekan beton pada penelitian ini, meski di dalam air laut telah dipengaruhi oleh penambahan silica fume dalam beton PCC sehingga menjadikan beton lebih kedap. Untuk mendapatkan beton yang tahan terhadap lingkungan agresif seperti zona pasangsurut air laut, menurut Supartono (2001), bahan tambah mineral seperti abu terbang, slag dan silica fume sering digunakan dalam aplikasi. Hasil penelitian Olivia \& Indrawan (2013) juga menunjukkan kekuatan tekan beton memakai silica fume tetap meningkat meskipun menggunakan pasir laut yang mengandung ion klorida.

\subsection{Kuat Tarik}

Gambar 5 menunjukkan hasil pengujian kuat tarik belah beton $\mathrm{PCC}$ dan $\mathrm{PCC}+\mathrm{SF}$ pada umur 28, 91, dan 180 hari setelah terendam air laut.

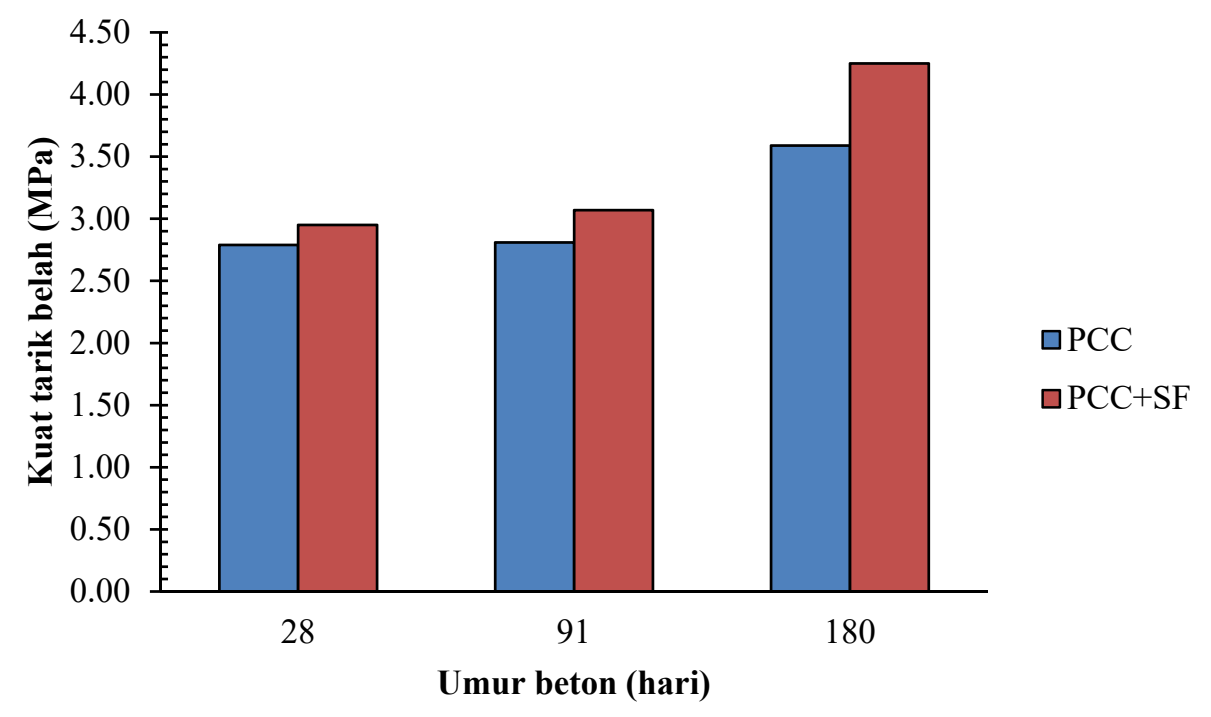

Gambar 5. Kuat tarik belah beton PCC dan PCC-Silica Fume di air laut pada umur 28, 91, dan 180 hari.

Kedua jenis beton sama-sama menunjukkan terjadinya kenaikan kuat tarik secara berkala meskipun benda uji direndam di zona pasang-surut laut. Kuat tarik beton meningkat sebesar $0,72 \%$ pada beton PCC, sedangkan beton $\mathrm{PCC}+\mathrm{SF}$ terjadi kenaikan lebih tinggi lagi dari beton PCC yaitu sebesar $4.07 \%$ setelah umur 28 hari. Kenaikan kuat tarik kedua tipe beton pada umur awal cukup lambat dibandingkan kenaikan kuat tarik setelah 28 hari. Beton PCC dan $\mathrm{PCC}+\mathrm{SF}$ mengalami kenaikan kuat tarik sebesar $27,76 \%$ dan $38,44 \%$ pada 180 hari. Kenaikan kuat tarik yang tinggi tersebut menunjukkan adanya peningkatan lekatan antar agregat dan matriks beton meskipun telah direndam dalam air laut. Berdasarkan hasil penelitian Ollivier et al. 1995, silica fume dalam beton PCC+SF berperan membantu ikatan antara agregat dan matriks melalui reaksi pozzolanik dan berfungsi sebagai microfiller yang mengisi Interfacial Transition Zone (ITZ) sehingga lekatan antara kedua fase lebih kuat. 


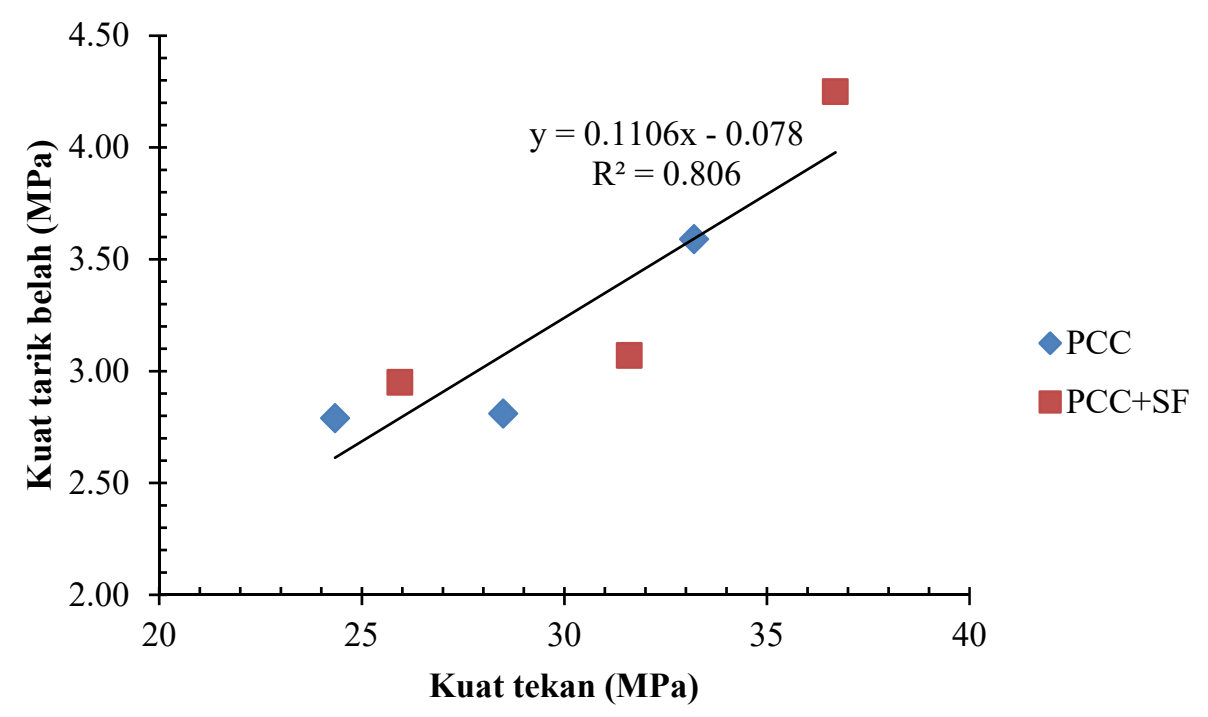

Gambar 6. Hubungan antara kuat tekan dan kuat tarik beton PCC dan PCC-silica fume di air laut pada umur 28, 91, dan 180 hari.

Korelasi antara kuat tekan dan kuat tarik belah dapat dilihat pada Gambar 6. Pada gambar dapat dilihat bahwa perbandingan kuat tekan dan kuat tarik berbanding lurus, yakni kuat tekan terus meningkat seiring dengan peningkatan nilai kuat tarik untuk kedua jenis beton PCC dan PCC+SF. Hal ini menunjukkan bahwa nilai kuat tekan berpengaruh pada kuat tarik beton yang dihasilkan. Berdasarkan hubungan ini, nilai $\mathrm{R}^{2}=0,80598$ mendekati 1,0 memperlihatkan hubungan kuat tekan dan kuat tarik yang baik. Peningkatan kuat tekan dan kuat tarik pada beton $\mathrm{PCC}+\mathrm{SF}$ dipengaruhi oleh penambahan silica fume, sehingga dalam penelitian ini nilai perbandingan kuat tekan dan kuat tarik selalu lebih besar daripada beton PCC.

\subsection{Porositas}

Pada Gambar 7 dapat dilihat perubahan porositas beton PCC dan $\mathrm{PCC}+\mathrm{SF}$ pada umur 28, 91, dan 180 hari. Porositas kedua jenis beton mengalami penurunan sangat signifikan sebesar $89,29 \%$ dan $96,13 \%$ menjadi $8,32 \%$ dan $6,03 \%$ untuk beton PCC dan PCC+SF setelah 28 hari. Proses hidrasi pada beton dan perawatan dalam air laut meskipun di zona pasang-surut dapat mengurangi porositas dengan cepat karena terjadi terus-menerus. Setelah 28 hari, pada beton PCC porositas menurun hingga 66,67\% yakni sebesar 0,30\%. Sedangkan pada beton $\mathrm{PCC}+\mathrm{SF}$, tidak terjadi perubahan nilai porositas sebesar $0,23 \%$ karena beton menjadi sangat kedap pada umur 91 hari. Hasil penelitian Turkmen (2003) dan King (2012), mengatakan bahwa penambahan silica fume yang memiliki partikel halus dapat mengisi pori-pori mikro dalam pasta semen, sehingga dapat mengurangi permeabilitas dan porositas lalu meningkatkan sifat mekanik dan durabilitas beton. Pada penelitian ini, porositas beton PCC+SF lebih rendah daripada beton PCC dan menunjukkan efek penambahan silica fume dalam meningkatkan ketahanan beton di air laut. 


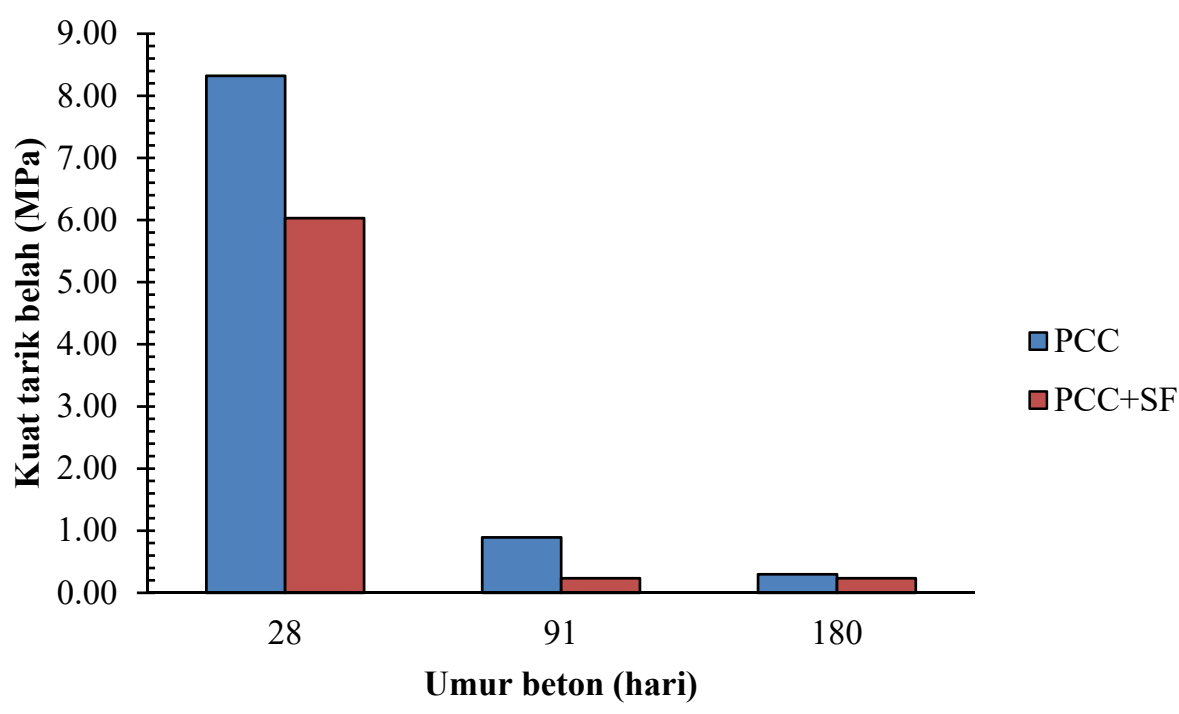

Gambar 7. Porositas beton PCC dan PCC-silica fume di air laut pada umur 28, 91, dan 180 hari.

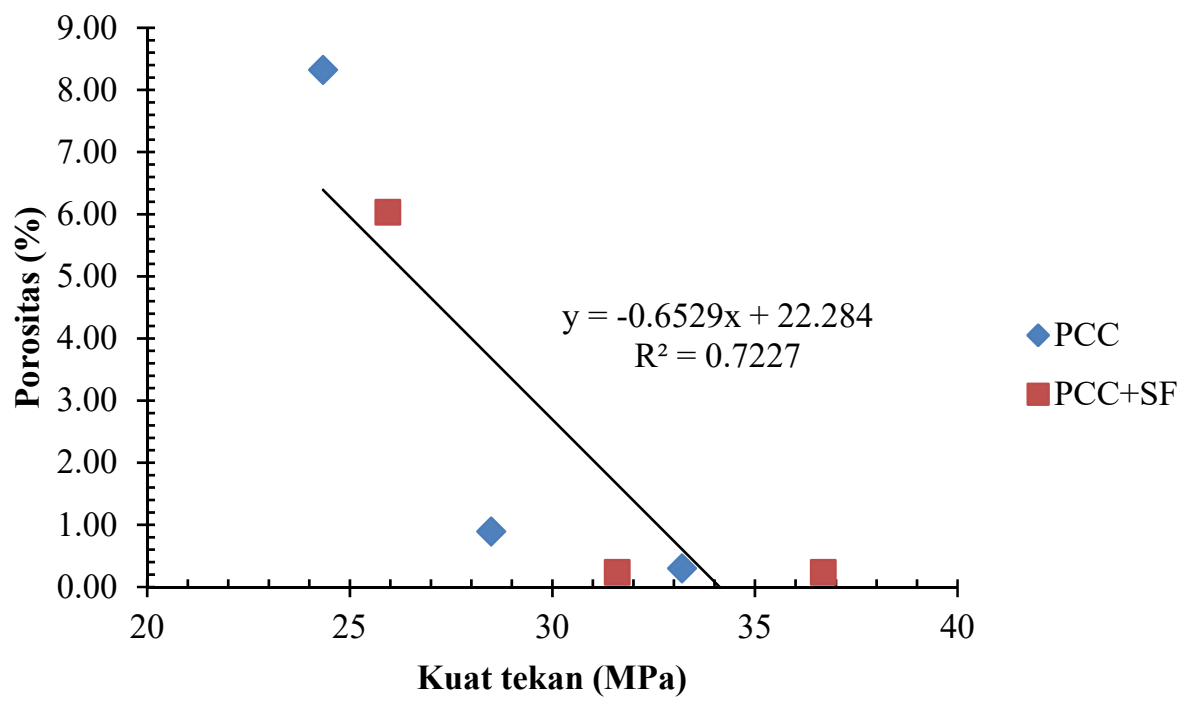

Gambar 8. Hubungan antara kuat tekan dan porositas beton PCC dan PCC-silica fume di air laut pada umur 28, 91, dan 180 hari

Porositas memiliki nilai penting pada beton karena porositas berhubungan langsung dengan sifat mekanik beton seperti kekedapan, keawetan bahkan dengan kekuatan beton. Pada Gambar 8 dapat dilihat bahwa korelasi kuat tekan dan porositas beton PCC dan PCC+SF berbanding lurus dengan $\mathrm{R}^{2}=0,72275$. Secara umum porositas menurun seiring dengan peningkatan kuat tekan terutama untuk beton $\mathrm{PCC}+\mathrm{SF}$.

\section{SIMPULAN DAN SARAN}

Pada penelitian ini dua jenis beton menggunakan semen PCC dan semen PCC+SF dengan tambahan silica fume diletakkan pada zona pasang-surut lingkungan air laut sampai dengan umur 180 hari. Pengujian yang dilakukan adalah kuat tekan, kuat tarik dan porositas. Hasil 
penelitian menunjukkan peningkatan kuat tekan dan kuat tarik beton serta penurunan porositas setelah terendam air laut. Beton PCC belum mencapai target kuat tekan fc' $30 \mathrm{MPa}$ pada umur 28 dan 91 hari, tapi beton $\mathrm{PCC}+\mathrm{SF}$ telah mencapai kuat tekan rencana pada umur 91 hari. Hasil penelitian juga menunjukkan bahwa penambahan silica fume pada semen tipe PCC menunjukkan nilai kuat tekan, kuat tarik belah dan porositas yang lebih baik. Seiring dengan umur beton, kenaikan kuat tekan mempunyai korelasi dengan kenaikan kuat tarik belah dan penurunan porositas. Kuat tekan beton meningkat, sejalan dengan kuat tarik yang meningkat serta porositas yang mengecil. Berdasarkan hasil pengujian dapat disimpulkan bahwa beton dengan semen PCC perlu menggunakan bahan tambah seperti silica fume agar memiliki ketahanan dan kekedapan yang diperlukan untuk dibangun di zona pasang-surut lingkungan air laut.

\section{UCAPAN TERIMAKASIH}

Ucapan terima kasih disampaikan kepada rekan-rekan yang telah membantu penyelesaian benda uji di lapangan.

\section{DAFTAR PUSTAKA}

King, D. (2012). The effect of silica fume on the properties of concrete as defined in Concrete Society Report 74, cementitious materials. In 37th Conference on Our World in Concrete \& Structures, 29-31 August 2012, Singapore (pp. 29-31)

Labib, N. M., Setyawan, A., \& Sumarsono, A. (2016). Analisis reaksi alkali silika agregat terhadap kuat tekan dan kuat lentur beton untuk perkerasan kaku yang tahan terhadap air laut. Matriks Teknik Sipil, 602-609.

Mehta, P. Kumar. (1991). Concrete in Marine Environment. Elsevier Applied Science, London \& New York, pp: $77-85$

Mulyono, T. (2004). Teknologi Beton. CV Andi Offset, Jogjakarta.

Ollivier, J.P., Maso, J.C., \& Borudette, B. (1995). Interfacial Transition Zone in Concrete. Advanced Cement Based Materials, 2(1), 30-38.

Olivia, M., \& Indrawan, B. (2013). Sifat Mekanis dan Rembesan Beton Mutu Tinggi Menggunakan Agregat Halus Pasir Laut dan Bahan Tambah Silica Fume. Jurnal Sains dan Teknologi , 12(1), $7-11$.

Ping, G., Beaudoin, J.J., Min, H. Z., \& Malhotra,V.M. (1999). Performance of Steel Reinforcement in Portland Cement and High-Volume Fly Ash Concretes Exposed to Chloride Solution. ACI Materials Journal, 96(5), 551-558.

SNI (2004). SNI 15-7064-2004: Semen portland komposit. Jakarta: Badan Standardisasi Nasional.

Sudarmoko. (1995). Pengaruh Abu Sekam Padi (Rice Husk Ash) Pada Kuat Tekan Beton. Media Komunikasi Tenik Sipil, 6(1), 8-11.

Sudjono, A.S. (2005). Prediksi Waktu Layan Bangunan Beton Terhadap Kerusakan Akibat Korosi Baja Tulangan. Civil Engineering Dimension, 7(1), 6 - 15.

Supartono, F.X. (2001). Beton Bahan Dasar dan Unsur Kekuatannya. Di dalam: Anonim. Trend Teknik Sipil Era Milenium Baru. Bandung: Yayasan John Hi-Tech Idetama.

Tjokrodimuljo, K. (1996). Bahan Bangunan. Yogyakarta: Teknik Sipil.UGM

Turkmen, I. (2003). Influence of different curing conditions on the physical and mechanical properties of concretes with admixtures of silica fume and blast furnace slag. Materials Letters, $57(29), 4560-4569$. 